\title{
Translating Partnerships: How Faculty-Student Collaboration in Explorations of Teaching and Learning Can Transform Perceptions, Terms, and Selves
}

Followed by Student Response by Hannah Silvers

\section{ABSTRACT}

Linguistic, literary, and feminist studies define translation as a process of rendering a new version of an original with attention to context, power, and purpose. Processes of translation in the context of student-faculty co-inquiry in the Scholarship of Teaching and Learning offer examples of how this re-rendering can play out in the realm of academic development. In this article, translation serves as a conceptual framework that allows us to bring a fresh interpretation to the collaborative work of participants in a student-faculty pedagogical partnership program based at two colleges in the mid-Atlantic United States. We argue that faculty members and student consultants who participate in this program engage in processes of translation that lead to transformed perceptions of classroom engagement, transformed terms for naming pedagogical practices, and, more metaphorically, transformed selves. Drawing on data from an ongoing action research study of this program and on articles and essays we and other participants in the program have published, we use a form of narrative analysis as it intersects with the conceptual framework offered by translation to illustrate how, through their collaboration, faculty and students engage in never-finished processes of change that enable mental perceptions, linguistic terms, and human selves to be newly comprehended, communicated, and expressed. We touch upon what is lost in translation as well and the necessity of ongoing efforts to make meaning through collaborative explorations, analyses, and re-renderings. Finally, we provide examples of how the changes participants experience and effect endure beyond the time of partnership and in other realms of their lives.

\section{KEYWORDS}

student-faculty partnership, translation, collaboration, transformation

Through my partnership with my student consultant, I have learned to engage in the process of evaluating my teaching on a consistent basis ... This experience has transformed me into a reflective practitioner. Faculty member

During my [semester in the role of student consultant], I developed confidence and trust in myself that extends beyond the [program] into all areas of my life. Student consultant

The college faculty member and undergraduate student quoted above are describing their experiences of transformation through student-faculty collaboration in explorations of teaching and 
learning. They are two among over 350 faculty members and undergraduate students who have participated in semester-long, one-on-one partnerships focused on analyzing pedagogical practice through the Students as Learners and Teachers (SaLT) program at Bryn Mawr and Haverford Colleges. As the director of and an experienced student consultant within the SaLT program, respectively, we have seen a wide range of ways in which extended collaborations between faculty members and undergraduate students support transformations like those described above. We have found translation a particularly powerful conceptual framework for analyzing the processes and outcomes of those transformations.

In this essay we draw upon arguments from linguistics, literary studies, and feminist studies to define translation as a process of rendering a new version of an original with attention to context, power, and purpose, and we point to processes of translation in the context of student-faculty co-inquiry in the Scholarship of Teaching and Learning (SoTL) through which teachers and students translate for one another in various ways. We then use a form of narrative analysis (Schutt, 2016) as it intersects with the conceptual framework of translation to analyze the processes and outcomes of faculty members and student consultants in creating transformed perceptions of classroom engagement, transformed terms for naming pedagogical practices, and, more metaphorically, transformed selves.

We concur with Healey, Flint, and Harrington (2014) that "engaging students and [faculty] effectively as partners in learning and teaching is arguably one of the most important issues facing higher education in the 21 st century" (p. 7). Because such engagement requires faculty and students to develop new language and new ways of being with one another, we need generative conceptual frameworks to support that development. Translation is an evocative combination of communicative and experienced change, which makes it a particularly rich conceptual framework for analyzing and supporting the processes of engagement that faculty and students experience in partnership, the specific contextual and relational qualities of these processes, and the transformations of language and sense of self that result.

\section{CONCEPTUAL FRAMEWORK}

As an interpretive framework, translation captures the iterative, analytical, and relational work of meaning making that unfolds in pedagogical partnership between student consultants and faculty members (Cook-Sather, 2006). It reinforces the necessity of both carrying forward and reshaping meaning as part of never-finished processes of change that enable mental perceptions, linguistic terms, and human selves to be newly comprehended, communicated, and expressed. Translation - the process - achieves such a transformation - the ever-changing result - through preserving some integral meaning and, at the same time, altering the perceptions and ways of being of those involved in the exchanges.

Feminist theory within translation studies calls attention to what Snell-Hornby (2006) describes as "the hitherto neglected factor of power in translation" (p. 164). Like women in literary, historical, and other areas of study, students themselves have been the objects of analysis rather than those "asking what is to be translated" or among those who decide "what criteria are used to make such choices" (Castro, 2009, p. 8). Positioning students as active participants in translation processes takes on the cultural hegemony and cultural identity $(\underline{\mathrm{Liu}, 2010})$ of students in educational analysis the way that feminist approaches take those on in relation to women and other marginalized or oppressed groups.

In SoTL, translation signals similar processes of revision that lead to transformation. For instance, Werder and Otis (2010) use this language to refer to how, when faculty and students study 
teaching and learning together, different questions, different language, and different analyses emerge and, as Otis puts it, faculty and students can "translate for each other" (p. 191).

All of these processes of translation produce transformed perceptions, communication, and sense of self. In a good translation, something of the original must always remain (see Agosin, 2000; Benjamin, 2000; Santos, 2000) albeit rendered anew. On the metaphorical level, in changing what one knows, one changes who one is (Dreier, 2003, in Wortham, 2004). In our understanding of the terms, then, in student-faculty partnerships focused on pedagogical practice, translation is the process through which particular outcomes are achieved: student consultants' and faculty members' perceptions of classroom engagement, terms for naming pedagogical practices, and identities or sense of self are transformed.

\section{CONTEXT, PARTICIPANTS, AND METHOD}

SaLT, the student-faculty partnership program that provides the context for our discussion of translating partnerships, is situated in the Bi-College Consortium of Bryn Mawr and Haverford Colleges, two small, selective, liberal arts colleges in the mid-Atlantic region of the United States. In this context, we (Alison and Sophia) occupy different roles and have different reasons for our shared interest in translation and student-faculty pedagogical partnership. Our methods reflect both our shared interests and the importance of including the voices of differently positioned participants through narrative analysis.

\section{Context}

Bryn Mawr and Haverford Colleges each enroll approximately 1,200 undergraduate students from diverse socio-economic, cultural, and educational backgrounds, offer a rigorous curriculum, have high teaching and research expectations for faculty, and strive to foster a sense of independence and social responsibility in their students. Both Bryn Mawr and Haverford Colleges are known for their student-centered approaches to teaching and learning and their multiple opportunities for students to collaborate with faculty members in research and other arenas. Each school has a strong system of selfgovernance, and students self-regulate on both an academic and a social level through their respective honor codes. The ideals of each institution rest on a system of mutual trust and respect among all members.

\section{Participants}

Alison has been a member of the faculty at Bryn Mawr College since 1994, when she was hired to develop and lead the Bryn Mawr/Haverford Education Program, through which students seek a minor in educational studies or state certification to teach at the secondary level. In 2006, she created the $\underline{\text { SaLT }}$ program, which has become the signature program of the Teaching and Learning Institute at Bryn Mawr and Haverford Colleges. Translation is a conceptual framework she has used to explore formal education for a range of learners (Cook-Sather, 2001, 2003, 2006, 2009, 2012).

Sophia completed her undergraduate work at Bryn Mawr in 2015, pursuing a self-designed major called "Educational Identities and Empowering Pedagogy." She worked as a student consultant from her second year through graduation and conducted research in partnership with Alison and for Bryn Mawr College in relation to other programs. Through each of these experiences she played 
multiple roles — student, peer, colleague, partner, facilitator, observer, researcher-and has thought about translation in relation to all of them.

Since 2006, more than 200 faculty and 150 student consultants have participated in the SaLT program. Through this program, individual faculty members work in one-on-one partnerships with undergraduate students not enrolled in their courses and sometimes not even familiar with the subject they are teaching. Any undergraduate student may apply to work in the role of student consultant; the program does not require a certain grade-point average or any other academic criteria but asks that applicants have experience in some sort of leadership role and be committed to thinking about teaching and learning. All applicants respond to two questions about why they want to be consultants and what experiences and capacities they bring, and each secures a recommendation from a faculty or staff member and from a peer. Partnerships are arranged according to scheduling compatibility with priority going to $4^{\text {th }}$-year students ( ince $2^{\text {nd }}$ - and $3^{\text {rd }}$-year students will have other opportunities).

Consultants and their faculty partners receive guidelines for developing partnerships that are meant as just that-guidelines rather than prescriptions. Consultants agree that 'training' prior to participation would not be helpful, so they participate in a short orientation and are paid a stipend for roughly six hours per week of work that includes observing one of their faculty partners' class sessions per week, taking detailed observation notes, meeting weekly with their faculty partners, and meeting weekly with other consultants and with Alison in her role as director of the program. In these weekly meetings consultants are supported, both by Alison and by one another, as they build their partnerships, each of which develops in a unique way.

\section{Method}

Since the advent of the SaLT program in 2006, Alison has engaged in IRB-approved action research ${ }^{1}$ to study participants' experiences and the outcomes of partnership and has published numerous articles alone and in collaboration with participants, including Sophia, on the findings (e.g., Cook-Sather, 2008, 2011b, 2014; Abbot, Cook-Sather, \& Hein, 2014; Cook-Sather \& Motz-Storey, 2016). In addition, since 2010, student and faculty participants have published reflective essays about their experiences and insights in Teaching and Learning Together in Higher Education, a journal created to showcase student-faculty pedagogical partnerships. In this discussion we apply a form of narrative analysis (Schutt, 2016) to Alison's research findings, some of which are drawn from original data and some of which are cited in publications, and to the published reflective essays of participants.

Narrative analysis "seeks to put together the 'big picture' about experiences or events as the participants understand them" (Schutt, 2016, p. 194). While participants do not necessarily use the language of translation to describe their experiences, either in the original data or in the essays they write, they consistently describe transformations like those articulated by the faculty member and student consultant with whose words we opened this article. To illuminate the nature of the experiences and of the outcomes of these transformations articulated by participants in a variety of ways, we use the conceptual framework of translation for the way it helps us re-see and bring a fresh interpretation to these experiences of transformation. We include representative excerpts from both original data and publications that capture the experiences participants had in their own words and that are particularly resonant with the conceptual framework of translation.

\section{TRANSLATION THROUGH STUDENT-FACULTY COLLABORATION}

We focus on two particular forms of translation that illustrate how participants generate new versions of perceptions and terms and new versions of selves with attention to context, power, and 
purpose. The first form of translation captures the way partnerships change faculty members' and student consultants' perceptions of classroom interaction, alter articulation of those perceptions, and, in turn, translate those into more refined or effective practices. The second form offers glimpses into the ways these and other forms of translation through partnership change student consultants' and faculty members' selves into new versions of those selves.

\section{Translating perceptions and terms}

Steiner (1998) reminds us that "human communication equals translation" (p. 49). When student consultants sit in their faculty partners' classrooms, taking observation notes focused on pedagogical issues their faculty partners have identified, they embark on a multi-step translation process. The first step is recording what they see in their own language - a process that includes the translation that happens in their own minds (what their particular brains and eyes select to note) and in the representation of those perceptions in their notes. Then, the consultants translate the notes into a version of what they observed that uses second-person pronouns and carefully crafted reflections that are at once true to their observations and articulated in a way that faculty can process without becoming defensive. To assist faculty in interpreting the notes, many consultants include short summaries, questions, or explanations regarding the points they make at the end of their notes that help, as one consultant explained, make the feedback "as soft as possible [for my faculty partner to take in]." Below is a short excerpt from the notes a student consultant took during one observation:

\begin{tabular}{|c|c|c|}
\hline TIME & OBSERVATIONS & REFLECTIONS \\
\hline $12: 22$ & $\begin{array}{l}\text { You ask a question that relates the } \\
\text { reading to the presentation. }\end{array}$ & $\begin{array}{l}\text { It's really helpful that you bring the material that the } \\
\text { presenter is covering back to the text. Not only are you } \\
\text { making good connections, but you are setting an example } \\
\text { that the reading is an active and necessary part of the class. }\end{array}$ \\
\hline $12: 28$ & $\begin{array}{l}\text { You interrupt the speaker a few } \\
\text { times to provide additional } \\
\text { information. }\end{array}$ & $\begin{array}{l}\text { It's important realize that there will be some connections } \\
\text { that you cannot make in order to maintain the fluidity. Also, } \\
\text { the fewer comments you make, the more powerful the ones } \\
\text { you do make will be. } \\
\text { You were really supportive of your students' perspectives, } \\
\text { but not overly so. In future classes, you might actually want } \\
\text { to play the devil's advocate more. It seems like all your } \\
\text { students are really on the same page about the issues that } \\
\text { you are talking about (with some small variations); it will } \\
\text { strengthen their ability to bring the arguments into the real } \\
\text { world if they have to argue to defend and verify their beliefs. }\end{array}$ \\
\hline $12: 45$ & $\begin{array}{l}\text { You ask a question and then wait a } \\
\text { few moments in silence to wait for } \\
\text { people answer, and then a student } \\
\text { who has not yet spoken answers. }\end{array}$ & $\begin{array}{l}\text { This student clearly just needed a little bit of time to } \\
\text { formulate her answer, and once she spoke she had good } \\
\text { thoughts. It was really important and beneficial that you } \\
\text { embraced this "wait time." }\end{array}$ \\
\hline
\end{tabular}


It takes student consultants time to develop the capacities both to perceive and to articulate their perceptions - to make informed decisions about how to identify and translate what they observe. Often for first-time consultants, what dominates perception is initially informed by the student experience; students comment on the challenges they face when they find their note taking resembles usual class notes that focus on content. As one consultant explained, she started out by "feverishly writing down people's points, the teacher's writing on the board, etc." Realizing that this was not the mode required in her role as consultant, this student "transitioned into student consultant role [and] wrote down observations and reflections, trying to focus on how the class was interacting, the professor's role." In these comments, this consultant narrates her translation of both perceptions and terms; she makes an aspect of classroom participation newly accessible to her own comprehension and also renders it anew in her communication through her observation notes.

As notes shift focus to pedagogy rather than specific content, student consultants develop a new perspective on the classroom, one that is separate from either student or faculty. As one consultant commented: "I think in exactly the way [my faculty partner] wasn't aware of how successful [a particular activity] was, students may not be aware of how they're impacting the class." In the context of noting the way a student's tone of voice or stance may impact whether other students feel supported enough to make themselves vulnerable in class participation, this consultant connects the limitation of one's awareness when caught up in teaching and the limitation of another's awareness when caught up in learning. Her third perspective, neither entirely teacher nor entirely student, gave her insight into the success of a classroom activity and the dynamics of the class that the views of student or teacher alone could not clearly provide. With this distanced perspective, student consultants find themselves in a position to observe a variety of things neither students enrolled in the course nor faculty can entirely see. Student consultants then re-present those perspectives to their faculty partners in their observation notes and in their one-on-one meetings in ways that are accessible and useful to their faculty partners.

As with any translation, there are perceptions and terms that can neither be captured nor rerendered precisely. Student consultants are not omniscient nor do they notice everything, and part of the translation process is choosing what to foreground and what to downplay or leave out. The weekly student consultant meetings provide a context within which to discuss how best to phrase difficult-totranslate perceptions and comments, but as with all translations, the final product both preserves something of the previous versions and creates a new representation.

When faculty can see versions of their practice re-presented to them in the student consultants' translations, they find ways of expressing their often un-articulated pedagogical commitments. They translate what might be partial formulations only in their minds into words that they can share with their consultants and, in turn, with their students. One faculty member explained that, as a result of receiving weekly observation notes and talking through those with her student consultant, she became "much more aware of the atmosphere in my classroom and better able to point out and articulate (to myself or others) what is and is not working the way I want." Like the consultant perceiving and describing classroom engagement in new ways, this faculty member both perceived anew and found terms to convey her new perceptions.

Student consultants, faculty members, and students enrolled in those faculty members' courses each have different perceptions of what is happening in classrooms. The terms and ways of communicating across them that student consultants and faculty members develop in partnership constitute forms of translation. Student consultants can, because of their in-between position, take on a unique role not only of interpreting and representing classrooms in new ways but also of interpreting 
and translating between faculty members and the students enrolled in their courses. Indeed, in one partnership, a student consultant found that the majority of the conflicts that arose in the classroom between the faculty and students were merely miscommunications. She explained:

I've spent a lot of time mediating discussions with students in the class and then participating in discussions with the professors and I find my work consists primarily in translation. I've been translating student voices to something professors can work with.

In this sense, her occupation of a third space allowed her to help each group better "read" and make sense of the other. In that third space, the student consultant translates her own perceptions into descriptions and analyses of the classroom and helps interpret students' experiences and perspectives for faculty members' understanding.

This consultant's explanation echoes Otis' point about how faculty and students can "translate for each other" (Werder \& Otis, 2010, p. 191). In collaboration, the student consultant and faculty member both develop new perceptions, new terms, and new capacities for employing those to analyze and, where appropriate, employ these translation processes to render transformed pedagogical practices. Student consultants, then, are translating both what is happening in the classroom by highlighting a third perspective that is neither student nor faculty member, and also what they understand students and faculty members are saying or failing to say to one another.

\section{Translating selves}

On the metaphorical level, student consultants and faculty translate themselves into new versions of those selves through their partnerships. These transformations are empowering: both student consultants and faculty members become more informed (by multiple perspectives), more confident, and more capable of risking and undertaking a wider range of forms of communication and practice. They embrace "the hitherto neglected factor of power in translation" (Snell-Hornby, 2006, p. 164) by including students in deciding "what is to be translated" and "what criteria are used to make such choices" (Castro, 2009, p. 8). Drawing on two essays published in Teaching and Learning Together in Higher Education in which a faculty member and a student, respectively, describe their transformations through working together in a SaLT partnership, we foreground their own narratives of translations of self.

Kurimay (2014) explains in her essay focused on her work with her student consultant, Alexandra Wolkoff, that their partnership "was an important step in developing my own teaching style and translating my aspirations into a more tangible action plan.” Her consultant's notes brought her attention "to the parts of the class that had worked, which helped me identify concrete things I needed to change as well as those that I didn't." Like the faculty member quoted in the previous section, who became more aware of and better able to articulate her goals through partnership with her consultant, Kurimay (2014) explains, "I became more aware of how I interacted with students and what energy level I brought to class." The partnership "proved crucial for changing the dynamics of my class and consequently, in meeting my goals." Kurimay clearly names the change she effected and experienced:

In several ways, I shifted my focus from me to my students: regarding what they were getting from the class materials, the questions the material raised, and the ways I invited and responded 
to student engagement... rather than focusing on the questions I thought the class must answer I started paying attention to what questions the readings and discussions raised for the students.

Through shifting her focus from herself to her students, Kurimay translated herself into a studentcentered teacher - a profound shift for many faculty. This translation of herself resulted in a transformed classroom:

The effects were unmistakable. The class was transformed into a lively intellectual space where students took charge of the discussions and I became a facilitator. I talked less and when I did, I consciously worked on covering content that built on students' ideas. Each of these shifts moved me closer to the kind of teacher I wanted to become. (Kurimay, 2014)

Wolkoff, the student consultant with whom Kurimay worked in her SaLT partnership, also translated herself over the course of their collaboration. The opening statement of her essay on this experience captures the change she observed in herself: "The process of becoming a student consultant ... allowed me to think of myself as a leader for the first time” (Wolkoff, 2014). She entered the partnership knowing she would have leadership responsibilities in her role as a consultant, but because of her previous experiences, she "doubted the value of [her] insights and contributions" (Wolkoff, 2014). Her partnership with Kurimay changed Wolkoff's beliefs and practices. In her words:

Because this work is built upon close, collaborative relationships, the [SaLT program] creates a space in which my unique and inherent skills are not only valued but prove fundamental to my and my partnership's success; in this environment my abilities with introspection, active listening, communication, and compassion define leadership. (Wolkoff, 2014)

The confidence and capacity that Wolkoff developed through working with Kurimay, she explains, "carried over into all of my personal relationships so that I now observe myself engaging this same level of mindfulness when talking with my parents, close friends, and peers" (Wolkoff, 2014). She concludes her essay with this statement: "Learning how to best embody and be myself through my work with the [SaLT program] allows me to be a fuller and more authentic self in my life as a whole" (Wolkoff, 2014).

These glimpses into the processes of translation in which a faculty member and a student consultant engaged show how they make themselves newly accessible to comprehension, communication, and expression. They become new versions of themselves through a process of crafting themselves "within shifting fields of power and meaning" (Kondo, 1990, p. 10). Their collaboration is the constant that supports the processes through which they become transformed selves.

\section{WHAT IS LOST IN TRANSLATION?}

While much is gained in the translations we describe here, some of the changes participants experience feel, at first, like losses. Both student consultants and faculty members note that, once you engage in these processes of translation, you cannot go back to an earlier, simpler way of being as a student or a teacher. A consultant explained, for instance, "I now look at syllabi with a very critical eye" and "for the future, I definitely see my learning as an experience that requires reciprocity." These are positive changes, in a way, but they are more demanding and, when faculty are not receptive, more difficult. One consultant, who published an article with Alison about her experience, reflected that "it 
can create frustrations when you feel as though in certain arenas your voice is valued and invited, and in others you may just have to sit back and grit your teeth some because your feedback is not invited or may be clearly unwelcome" (Cook-Sather \& Alter, 2011, p. 48).

In terms of what is lost in translation for faculty, most comments from faculty participants center around the loss of a sense of teaching alone as "normal." Highlighting the way he translated himself from an autonomous teacher into a partner with his student consultant, one faculty member mused, "I just thought about this morning how wonderful it would be to have a student consultant for every class." He elaborated: "The great benefit is that there is someone in the classroom who is observing what is happening in that classroom in ways that I cannot do myself." This is lost if one settles for teaching solo rather than expanding invitations to other students and to colleagues after experiencing collaboration through the SaLT program. Another faculty member offered a more pointed reference to the loss: "I do not know that it would be practical to have a consultant attend every single class, but I bring this up as an example of how keenly I felt her absence on the days I was not able to debrief with her afterwards."

A further loss is that of more innocent notions of communication. We tend to assume that others understand us better than they, in fact, do. Engaging in the kinds of translation discussed here makes that apparent. One student consultant who worked in a SaLT partnership explained:

It becomes more and more clear that no experience is truly shared-everyone experiences a given situation in a different way, and any instance of understanding necessitates translation of those personal experiences. We are always translating ourselves to other people, and the only way to get good at it is through practice. (Student consultant qtd in Cook-Sather, 2011a, p. 52)

These losses - of simpler, more solitary, more naive ways of being and of the illusion that we ever really know what others mean by their words and ways of being - throw into relief the importance of collaboration and of translation as a conceptual framework to analyze and revise both discourse and pedagogical practices. Although they are experienced as losses, these changes become incorporated in the newer versions of faculty members and student consultants to constitute deeper and richer layers of the same selves.

\section{DO TRANSLATIONS EXTEND AND ENDURE BEYOND THE PARTNERSHIPS?}

The transformed perceptions, terms, and selves that faculty members and student consultants describe in the previous sections both extend beyond their immediate partnerships during collaboration and endure beyond the time of their partnerships. Both faculty members and student consultants describe the ways in which they translate how they think, speak, and engage.

Capturing the changes participants experience in perception and engagement, one faculty member wrote about her collaboration with her student consultant: "I quickly came to see our partnership as a model for professor-student partnerships more broadly" (Reckson, 2014) — a model that led her to extend opportunities to her students to collaborate with her. Another faculty member wrote, "I work with students more as colleagues, more as people engaged in similar struggles to learn and grow." This faculty member came to see students as "experts in learning and essential partners in the task of creating and developing new courses and refining existing ones." A third faculty member described how, through his collaboration with a student consultant, he began to collaborate more fully with all students enrolled in his courses: "Mid-way through the semester of working with my Student Consultant, I realized that I was thinking about my class in a more collaborative way than I had before: I 
was thinking about building the course with the students, as partners.” These transformations reflect revisions in faculty perceptions of students and constitute profound changes in ways faculty members work with students enrolled in their courses.

These transformations in perception and engagement inform faculty members' transformation of themselves. Capturing the experience many faculty have of increased clarity and confidence as a result of participating in pedagogical partnership, one faculty member mused:

[You gain] confidence not just in the classroom, not just in your office and on campus, but also off campus, at home. I feel a kind of peace in my heart, not anxiety- "Oh, how am I going to deal with this?” No, I feel peaceful in my heart and mind. So it affects all aspects of my life.

Likewise, when consultants come to the end of a semester of partnership, they often look back on their collaboration and realize the ways it has transformed them. For example, one consultant highlighted an irreversible shift in her perception: "Now that I have been so exposed to this level of awareness, I really don't think it would be possible for me to enter a classroom WITHOUT thinking about the way class is being taught (as opposed to simply what is being taught)." Another consultant described her expanded capacity to find terms to name what she perceives: "One of the most important things I will take away from this experience is the new vocabulary and skill set I have with which to communicate with professors." She specifies that she has both a new "skill set" and "a sense of how I might make suggestions for improvement "'hearable' to a professor outside of [the program]." A third consultant reflected on her transformed sense of herself as a student: "All of my classrooms feel like a partnership now, instead of the students versus the professor." These and many other reflections illustrate that, like their faculty partners, student consultants undergo profound changes in perception, expression, and practice that endure beyond the time of their partnerships.

Also like their faculty partners, student consultants experience transformations of themselves that extend beyond their collaborations. Reflecting the kind of transformation virtually all consultants experience, one former student consultant describes an enduring sense of capacity for and commitment to partnership and a greater sense of confidence and responsibility:

The lessons that I learned in those four semesters [of working as a student consultant] are still with me, and I went into my first day [of teaching] with great confidence in everything that I know and everything that I am. I know that wherever I go and whatever I do, I have a responsibility to express my thoughts, my experiences, and my voice. (Quoted in Cook-Sather, 2011a, p. 50)

\section{CONCLUSION}

Our title, "Translating Partnerships," strives to signal two sets of processes and outcomes. The first is the translations student consultants and faculty members experience through participating in the SaLT program: transformations of perceptions, terms, and selves. The second is our own interpretative and expressive experience: the process and outcome of our effort to use a form of narrative analysis as it intersects with the conceptual framework of translation to make the transformed perceptions, terms, and selves that participants in the SaLT program articulate newly accessible to comprehension, communication, and expression. 
The faculty members and student consultants we quote here are representative of the hundreds who are engaged in profound forms of translation through their collaboration. The new ways of naming and enacting powerful pedagogical practices that they develop together remind us that collaboration between faculty and students supports the ongoing processes of clarification and revision-of perceptions, terms, and selves - that can produce reflective practice, confidence and trust, thoughtful communication, student-centered teaching, and an enduring sense of capacity. These are all desirable forms of human experience and interaction and particularly important for engaged and meaningful learning and teaching.

Our effort to employ a form of narrative analysis and to bring a new conceptual framework to discussions of student-faculty pedagogical partnership within the Scholarship of Teaching and Learning was inspired both by our shared desire to find new ways of gaining insight into our work and experience, and by our hope that readers might also perceive anew the transformative potential of student-faculty pedagogical partnership through our effort to re-present that potential in a new way. The insights we gained through attempting "to put together the 'big picture' about experiences or events as the participants understand them" (Schutt, 2016, p. 194) within the conceptual framework translation offers afforded us the opportunity to revisit participants' reflections and to re-view them in terms of translation. Our co-authoring process and co-authored product mirror the collaborative work of pedagogical partnership: bringing (at least) two perspectives to bear on classroom teaching and learning and its analysis, and changing through the collaborative process the ways we understand terms, practices, and selves.

\section{ACKNOWLEDGMENTS}

Thanks to our editors for feedback and guidance on this essay and to Anita Kurimay, Elliott Shore, and Alexandra Wolkoff for their feedback and suggestions.

Alison Cook-Sather is the Mary Katharine Woodworth Professor of Education and Director of the Teaching and Learning Institute at Bryn Mawr and Haverford Colleges.

Sophia Abbot graduated from Bryn Mawr College in 2015 and is currently a Fellow at Trinity University's Collaborative for Learning and Teaching, where she leads research and programming on student-faculty collaborations.

\section{NOTE}

1. With a history dating back to the 1930s (Adelman, 1993), action research is a well-developed approach in the United Kingdom and the United States. Striving to address "practical questions evolving from everyday educational work" (Altrichter, Posch, \& Somekh, 1993, p. 5), action research involves moving repeatedly through the "spiral of self-reflective cycles" of planning a change, acting and observing the consequences of the change, reflecting on these processes and consequences, and then re-planning (Kemmis \& Wilkinson, 1998, p. 21).

\section{REFERENCES}

Abbot, S., Cook-Sather, A., \& Hein. C. (2014). Mapping classroom interactions: A spatial approach to analyzing patterns of student participation. To Improve the Academy, 33(2), 131-152.

Agosin, M. (2000). A writer's thoughts on translation and always living in translation. MultiCultural Review, 9, 5659.

Adelman, S. (1993). Kurt Lewin and the origins of action research. Educational Action Research, 1, 1, 7-24, DOI: $10.1080 / 0965079930010102$ 
Altrichter, H., P. Posch, \& B. Somekh. (1993). Teachers investigate their work: An introduction to the methods of action research. London: Routledge.

Benjamin, W. (2000). The task of the translator. In Venuti J. L. (Ed). The translation studies reader (pp. 15-25). London: Routledge.

Castro, O. (2009). (Re)examinando horizontes en los estudios feministas de traducción: ¿Hacia una tercera ola? [(Re)examining horizons in feminist translation studies: Towards a third wave?]. (transl. M Andrews). MonTI 1, 59-86.

Cook-Sather, A. (2001). Between student and teacher: Learning to teach as translation. Teaching Education, 12(2), 177-190.

Cook-Sather, A. (2003). Education as translation: Students transforming notions of narrative and self. College Composition and Communication, 55(1), 91-114.

Cook-Sather, A. (2006). Education is translation: A metaphor for change in learning and teaching. Philadelphia: University of Pennsylvania Press.

Cook-Sather, A. (2008). "What you get is looking in a mirror, only better:" Inviting students to reflect (on) college teaching. Reflective Practice 9(4), 473-483.

Cook-Sather, A. (2009). Translation: An alternative framework for conceptualizing and supporting school reform efforts. Educational Theory, 59(2), 217-231. DOI: 10.1111/j.1741-5446.2009.00315.x

Cook-Sather, A. (2011a). Layered learning: Student consultants deepening classroom and life lessons. Educational Action Research, 9(1), 41-57.

Cook-Sather, A. (2011b). Teaching and learning together: College faculty and undergraduates co-create a professional development model. To Improve the Academy, 29, 219-232.

Cook-Sather, A. (2012). Translating learners, researchers, and qualitative approaches through investigations of students' experiences in school. Qualitative Research, 13(3), 350-365. (published online before print August 13, 2012. Doi: 10.1177/1468794112451022).

Cook-Sather, A. (2014). Multiplying perspectives and improving practice: What can happen when undergraduate students collaborate with college faculty to explore teaching and learning. Instructional Science, 42, 3146.

Cook-Sather, A., \& Alter, Z. (2011). What is and what can be: How a liminal position can change learning and teaching in higher education. Anthropology \& Education Quarterly, 42(1), 37-53.

Cook-Sather, A., \& Motz-Storey, D. (2016). Viewing teaching and learning from a new angle: Student consultants' perspectives on classroom practice. College Teaching, 59(4).

Healey, M., Flint, A., \& Harrington, K. (2014). Students as partners in learning and teaching in higher education. York, England: Higher Education Academy.

Kemmis, S., \& Wilkinson, M. 1998. Participatory action research and the study of practice. In B. Atweh, S. Kemmis, and P. Weeks (Eds.), Action research in practice: Partnerships for social justice in education (pp. 21-36). New York: Routledge.

Kondo, D. K. (1990). Crafting selves: Power, gender, and discourses of identity in a Japanese workplace. Chicago: University of Chicago Press.

Kurimay, A. (2014). From tennis to teaching: The power of mentoring. Teaching and Learning Together in Higher Education, 11.

Liu, L. (2010). Cultural turn of translation studies and its future development. Journal of Language Teaching and Research, 1(1), 94-96.

Reckson, L. V. (2014). The weather in Hemingway. Teaching and Learning Together in Higher Education, 11.

Santos, S. (2000). A la recherche de la poesie perdue (poetry and translation). American Poetry Review, 29(3), 9-14.

Schutt, R. K. (2016). Understanding the social world: Research methods for the 21st century. Los Angeles: Sage Publications.

Snell-Hornby, M. (2006). The turns of translation studies: New paradigms or shifting viewpoints? Amsterdam: John Benjamins Publishing.

Steiner, G. (1998). After babel: Aspects of language and translation (3rd ed). London: Oxford University Press.

Werder, C., \& Otis, M. M. (2010). Not the conclusion: Moving from engaging to sustaining student voices. In C. Werder \& M. Otis (Eds.), Engaging student voices in the study of teaching and learning (pp. 185-194). Sterling, VA: Stylus.

Wolkoff, A. (2014). Teaching and learning as learning to be: Finding my place and voice as a leader. Teaching and Learning Together in Higher Education, 11.

Cook-Sather, A., \& Abbot, S. (2016). Translating partnerships: How faculty-student collaboration in 


\section{Student Response to “Translating Partnerships: How Faculty-Student Collaboration in Explorations of Teaching and Learning Can Transform Perceptions, Terms, and Selves"}

When reading about the translation of SaLT student consultants' observations to their professor partners, this sentence struck me: "As one consultant explained: 'One thing I do in my notes is have a section at the bottom of questions or suggestions, and I put them all in the form of a question so it's as soft as possible [for my faculty partner to take in].” The sentence struck me because I'm sure I would do the same thing if I were a consultant-especially if I were paired with a professor I didn't know in a discipline I wasn't familiar with. I would probably feel intimidated by the idea of providing feedback on a professor's methods, particularly critiques.

The authors describe the SaLT program as a way to overcome the natural power difference between professors and students, the source of that intimidating feeling. As informed by feminist theory, part of the program's purpose is to take students from the objects of educational analysis and reposition them as the subjects, therefore empowering them. I wonder, though, as I think about the quoted consultant's response and what my approach would be, how much of that inherent intimidating feeling carries over regardless, and what that feeling means for the results of the partnerships.

Translating the consultant's observations into something the professor can use is a multi-step process informed by factors besides their classroom observations. The result of this translation is, according to the authors, "carefully crafted reflections that are at once true to their observations and articulated in a way that faculty can process without becoming defensive." With consultants "carefully crafting" their reflections, I can see how useful observations could get lost in translation because they feel like they don't know how to present their critical observations to professors in a deferential way.

Thinking about how I would navigate this translation process, I think I would need some help. I would want my reflections to be "true" to my observations, but I would worry about my presentation and the effect it could have on my relationship with my professor. My first thought is training for consultants - but as the authors note, current consultants don't think traditional training is necessary. I wonder if consultants were offered workshops on presenting observations, maybe workshops led by previous consultants with examples of previous reflections, if they would find them useful. I know I would. 
Hannah Silvers is an undergraduate student at Elon University who holds a major in English with concentrations in Professional Writing and Rhetoric (PWR) and Creative Writing as well as a minor in Economics.

(c) (1)

Copyright for the content of articles published in Teaching \& Learning Inquiry resides with the authors, and copyright for the publication layout resides with the journal. These copyright holders have agreed that this article should be available on open access under a Creative Commons Attribution License 4.0 International (https://creativecommons.org/licenses/by/4.0). The only constraint on reproduction and distribution, and the only role for copyright in this domain, should be to give authors control over the integrity of their work and the right to be properly acknowledged and cited, and to cite Teaching \& Learning Inquiry as the original place of publication.

Readers are free to share these materials - as long as appropriate credit is given, a link to the license is provided, and any changes are indicated. 